\title{
Investigating Awqaf Management, Accounting and Investment Practices in Malaysia: The Case of a State Religious Institution
}

\author{
Hisham Yaacob (Corresponding author) \\ Department of Accounting, College of Business and Economics, \\ United Arab Emirates University, Al Ain, United Arab Emirates. \\ Tel: +971-3-7673333 E-mail: annasham@yahoo.com \\ Hairul Suhaimi Nahar \\ Department of Accounting and Finance, Universiti Putra Malaysia, \\ 43400 Serdang, Selangor, Malaysia \\ Tel: +603-89467629 E-mail: hairulsuhaimi@upm.edu.my \\ AND \\ Department of Accounting, College of Economics and Political Science, Sultan Qaboos \\ University, Al Khoud, Muscat, 123, Sultanate of Oman
}

\begin{abstract}
Social economy is gaining interest as an alternative to capitalist economy. As compared to its capitalist counterpart, social based economy is ethically and morally guided. This arguably possesses close alignment to the religious based economy among Muslims - The Islamic Economics. Waqf, which is equivalent to endowment in the non-Islamic context, is an important institution in the Islamic socioeconomic system. Widely practiced among Muslims since the Prophet Muhammad's era, waqf has enhanced Muslims' socio-economic strength particularly during the Ottoman era. This research revisits such religiously founded practice by examining the contemporary waqf accounting, reporting and investment practices of a selected waqf manager in Malaysia - The State Religious Institution (SRI). Adopting a qualitative approach to research inquiry using a single case study method, data were collected through interviews and documents' review. The research finds observable weaknesses in the accounting, reporting and investment for waqf activities particularly on waqf assets. The available records suggest large improvement void in the focused areas, albeit it does not tantamount to detrimental effects on SIRC's efforts in adequately safeguarding the waqf assets. The research provides fresh evidence
\end{abstract}

of the contemporary accounting, reporting and investment practices of a religious institution entrusted to manage waqf funds operating in an emerging market.

Keywords: Waqf; Usufructs; Accounting; Reporting; Investments; Accountability

\section{Introduction}

The emergence of social economy as an alternative to capitalistic economy has attracted the academic interests of many contemporary scholars. Its social constructs are argued to have imbued and embedded with ethical and moral elements (Naqvi, 1981) and its objectives are closely aligned to Islamic economics. Economically, Islam demands that wealth is to be shared and circulated through various mechanisms based on justice and equity as outlined in the Qur'an and Ahadith (sayings of Prophet Muhammad) (Chapra, 1992). The mechanisms include waqf (Islamic endowments) and charities which are important elements in the social economy as they provide public goods such as education and healthcare (Khan, 1994), provision of religious premises and utilities, jobs opportunities and public library without any cost to the government (Yedyyildiz, 1996). Historical records in the Muslim world indicate that waqf is a self-sustainable socio-economic 
device (Cizakca, 1998; Nasution, 2002) and it provides solutions to many social and economic problems such as poverty alleviation (Hoexter, 1998; Sadeq, 2002; Hasan, 2014) and capital financing (Cizakca, 1998).

Although these sectors are heavily regulated in developed countries such as the United Kingdom, United State and Singapore, many Islamic countries only have rudimentary legislative and governance framework to ensure the sustainability and proper management of the entities. The Charity Commission in the UK for example provides extensive guidelines (please see SORP, 2000 and 2005) which regulate all charities in the UK and Wales. Extant literature on endowments, non-profits, charities and religious organizations (e.g. church and mosque) noticeably covers aspects on administration, management, accounting, financial management and reporting and especially accountability of the managers (Cordery, Baskerville and Porter, 2011; Dhanani, 2009; Hooper et al., 2008; Hyndman, 1990; Hyndman and McDonnell, 2009; Jacobs, 2005; Jacobs and Walker, 2004; Laughlin, 1988; Lightbody, 1999; Yasmin et al., 2014). These studies are however concentrated on samples drawn from advanced economies where the entities operate, systematically contributing to the lack of understanding and analytical avenue which could improve these important institutions in the emerging economies, particularly in Muslim dominated countries.

For Muslims, adherence to the principles of Islam is a must. The central tenet in Islam is the tawheed (unity of god) (Bilal, 1994) which demands for Muslims to believe in one and only God-Allah, who creates human and subsequently appoints them as His vicegerent (khalifah) on earth to take care (i.e. trustee) of the bounties void of transgression (Sulaiman, 2003; AbdulRahim, 1998). Accordingly, wealth in terms of resources are to be managed with responsibility which human should not evade nor violate and they are accountable for all of their (in)actions (Abdul-Rahim and Goddard, 1998; Kamla,
Gallhofer and Haslam, 2006; Nahar and Yaacob, 2011). Such accountability is termed taklif which is based on dual accountability (Nahar and Yaacob, 2011) covering the accountability to the Creator (Allah) and accountability towards fellow human, nature and environment (Kamla et al., 2006).

Framing this research based on the above concept of taklif on waqf within the Islamic economics domain, this paper seeks to analyze and examine waqf accounting, reporting and investment practices in a selected SRI in Malaysia. It takes a case of a SRI-W which name is kept anonymous due to the sensitive nature of the data and the institution. The research analyzes and examines relevant documents on SRI-W's accounting, reporting and investments practices. A simple performance measurement calculation using return on waqf assets (ROWA) as a proxy to measure SRI-W's accountability was also carried out. It then compares the Statement of Recommended Practice (SORP 2005) issued by the Charity Commission, United Kingdom with the existing SRI-W's financial management and accounting policies, procedures and practices to explore for any improvement void. Finally, the paper further recommends accounting and reporting template relevant to improving SRIW's accountability. The paper believes that a proper accounting and reporting oversight model for waqf can be based on SORP 2005, appropriately modified to comply with the Shari'ah requirements.

The paper proceeds as follows. Next section reviews waqf and its practices in Malaysia, followed by a review of prior research in waqf accounting and reporting. The research method employed in this study is then described where the use of case study is appropriately explained. The empirical findings on accounting, reporting and investments practices obtained from the case study conducted are then presented. Final section concludes the paper. 


\section{Waqf and its Practices in Malaysia}

Waqf possesses unstandardized definition in the literature as the term itself is not specifically stated in the Quran (Zain, 1971). Islamic jurists however infer and explain waqf based on related Quranic verses and Ahadith. Extant literature literally defines waqf as confinement and prohibition (Hassan, 1984; Hashmi, 1984), denoting the restriction imposed on asset's usage and ownership upon its conversion into waqf status. There are four common types of waqf namely waqf khayri (general waqf), waqf khas (specific waqf), waqf ahli (private waqf) and cash waqf (Yaacob, 2013).

Waqf practices and hence its institutions began more than eight hundred years ago in Malaysia (Syed-Othman, 1986). It started when the Arab Muslim traders brought Islam to the peninsular land in the tenth century. Religious education is the main factor of waqf being developed in the country, especially in the state of Terengganu. This is evidenced by one of the early nineteenth century waqf deeds by Sultan Umar (the state ruler), stating the objective of his waqf is to promote education and the dissemination of knowledge to the public (Mahmood, 2000). During the earlier period, Muslims who wished to donate or convert their property into waqf would verbally appoint the village head or 'Penghulu' as the asset's trustee (Yaacob, 2013). In the absence of proper written records, problems arise when the 'Penghulu' passed away and is replaced by another person. The deceased's descendants in many cases did not declare the waqf property and subsequently used them as their private property (Baharuddin, 1998; Yaacob, 2013). The practice of waqf with proper documentation is rare pre 19th century except for the mosque building famously known as the Masjid Kapitan Kling (in 1801) and a building donated by the member of the Aceh royalty in Penang (Nasution, 2002).

Currently, waqf is managed by the respective State Religious Councils (SRCs) as the Federal Constitution of Malaysia provides that all
Islamic matters are under the State's purview (Nahar and Yaacob, 2011). Noticeably, waqf practices have long been neglected and nearly forgotten by the Malaysian Muslim community compared to the other Islamic institutions such as zakat (Islamic tax) (Abdul-Rahim et al., 1999; Baharuddin, 1998; Mahmood, 1998). Extant Malaysian waqf literature indicates various operational weaknesses ranging from lack of documentation to accountability among SRCs being the waqf manager (Nahar and Yaacob, 2011).

\section{Waqf Accounting and Reporting: Previous Research}

Many past studies on waqf mainly concentrated on its management and operational aspects (Deguilhem, 2003) and waqf property development and improvement (Hasanuddin, 1998; Mustapha, 1987). Research on waqf accounting, reporting and investments are however noticeably sparse with only limited literature available focusing on Algeria (e.g. Hoexter, 1998), Malaysia (Yaacob et al., 2015), North Africa (e.g. Shatzmiller, 1991), Singapore (e.g. Nahar and Yaacob, 2011) and Turkey (e.g. Toraman et al., 2007).

A study by Siti-Rokyah (2004) investigates waqf financial management and reporting practices of fourteen SRIs in Malaysia. The research finds large vacuum in the transparency continuum including timely preparation of annual reports and inadequate disclosure. Majority of the SRIs are found to have taken more than three years to complete an annual report without being penalized. This corroborates earlier findings indicating lack of competent managers and technical personnel working with unclear objectives and functions (Mohd-Yusop, 1999). Arguably, the lack of regulatory enforcement systematically provides incentives for SRIs to deemphasize the importance of providing timely and transparent financial accounting and reporting. In addition, majority of the SRIs did not also maintain a separate fixed assets register for waqf account, an observation that 
is consistent with that of Abdul-Rahim et al. (1999). The SRIs are further noted for not providing any allowances for depreciation on their non-current assets.

The above findings are consistent with results obtained by Zietlow's (1989) which was based on pure religious non-profit organizations in the United States, whereby only five percent of the agencies have five-year financial planning. Evidence indicating lack of financial management skills is also gathered by SitiAlawiyah (2004). Interestingly, Yaacob et al. (2015) found that the waqf manager that they examined employs only two staff but is able to successfully manage hundreds of millions of dollar worth of waqf assets and investments with the assistance of proper technology in its administration and financial management, accounting and reporting. A complete waqf assets register is available upon request by stakeholders whilst the financial statements are also available online.

The success story on waqf practices in Algeria was studied by Hoexter (1998) covering the period from the late 1700 s to 1830 . The research found that the preservation of waqf assets (guarding them from dilapidation or usurpation) had ensured continuous distribution of waqf income. The founder prioritized repairs over any other expenditure and that anything endangering waqf asset's continuous presence was ruled out, i.e. selling, mortgage, letting for a permanent/ long period were forbidden (only one year for urban and three years for rural). Strict follow up and efficient control of payments due by tenants and good work in maintaining and restoring of waqf assets under their control are obvious. Reference to the registers shows the purchase of materials for maintenance, and the waqf administrator even kept stocks (inventory) for repair purposes.

Historical review of waqf accounting is provided by Toraman et al. (2007) whose study was based on cash waqf during the Ottoman era. The study found that cash waqf transactions in Turkey circa 15 th and 16 th century were recorded using single entry accounting system and specific registers are also kept for waqf funds and payables. Similar documentary evidence was also found by Shatzmiller (1991) which examined waqf khayri in the 14th century in Fez, North Africa. The study documents systematic accounting records of income and expenditures of various waqf properties providing diverse public goods including 'hammam' (public bath house), 'madrasa' (schools), public kitchen and books for public library. These results are potentially useful in guiding the accounting and reporting practices of contemporary waqf managers, thereby effectively discharging their accountability to waqf stakeholders.

\section{Methodology}

This study aims at investigating current waqf accounting, reporting and investments practices of a selected SRI-W. It relied on verbal (interview) input, documents analysis and nonparticipant observation as these methods allow exploration of the organization and actors within their social context (Baxter and Jack, 2008; Firestone, 1987; Yin, 1994). Triangulation is applied to increase the reliability of the data and evidence collected (Moore, 2000; O'Leary, 2004). Accordingly, this present research adopts the qualitative approach whereby a case study method is utilized. Given the exploratory nature of this research, a single case study method is argued to be the best method to achieve the research objective (Cooper and Shindler, 2003; Maxwell, 1996; Travers, 2001; Baxter and Jack, 2008; Gillham, 2000). In addition, in view of the nearly restricted nature of access to the organization, single case study method remains the best option as the selected sample provide maximum access to the research site and documents. Case study approach is being utilized in prior research on accountability in organizations (e.g. Hodge, 2012).

SRI-W is chosen given its status as the most advanced SRI in Malaysia (Zainal-Abidin, 1999). The respondents (personnel of SRI-W) 
are identified and segregated into three groups. The first group consists of personnel in the waqf unit of the General Resources Department. The second group comes from the Investment and Development Division, who are responsible for the investments and development of SRIW's properties including waqf properties. The third group is the finance and administration personnel who handle matters related to the waqf financial management and accounting. These three groups are selected because they are the primary individuals directly involved with the preparation of waqf accounts, reporting and administration of waqf assets and investments.

\section{Results and Discussion}

Based on its organizational structure, the SRIW's Management Services Division handles the overall financial and reporting aspects of the institution. The division is headed by a Chief Assistant Director (CAD) and assisted by three accountants with assistants and support staff respectively. The Director of State Religious Department is automatically appointed as the Secretary of SRI-W.

\section{Administration and Management}

The administration and management of waqf fall under the sub-unit of Baitulmal Affairs within the General Resources Unit (GRU), which is headed by an Assistant Director (AD) with two support staff (clerical level). The AD reports to the Council's CAD who is under the State Islamic Department. During the interview, the CAD and AD confirmed the lack of skilled human resources to handle the administration and management of waqf property that has hindered effective management of waqf assets. The AD further described (from his perspective) a skilled person as:

"A person with adequate knowledge of administration and management especially in the shari "ah and operations"

Apart from constraint on the availability of skilled human resources, both $\mathrm{CAD}$ and $\mathrm{AD}$ also highlighted the lack of financial resources to develop waqf properties. They argued that the lack of human resources and financial resources dampens the effective management and much needed improvement of waqf properties especially landed properties. He further acknowledged unnecessary bureaucratic processes plaguing waqf management particularly on the process of transferring the land title at the Land Office if the land area is too small.

\section{Financial Regulations and Policies}

The main guidelines come from the "Shari' ah Administration Enactments 195X' (*The " $X$ " used throughout this paper is meant to maintain anonymity of SRI-W), 'Baitulmal Procedures (XX) (Expenditures and Application) (replacement)' 198X, section 2(b) which reads:

"replacement of sub section 3(a), No money or resources in the Consolidated Funds may be used for the purposes stated in Section 3 and 4 unless with the prior approval of the committee"

Section 3(b) stipulates that all approval by the committee must be reported to the Council and Section 3(c) states that the Council from time to time may give its orders which must be executed by the committee. These amendments were approved by the Cabinet on November 11, 198X and enforceable since May 9, 198X. Other guidelines such as Treasury Instruction, Circular Instruction and the Financial Reporting Standards by the Malaysian Accounting Standard Board are also applicable to SRI-W in recording and reporting its waqf transactions.

\section{Waqf Accounts}

Computerized accounting system named 'Sistem Kewangan dan Akaun MXXXX' (MXXXX Financial and Accounting System) was developed internally by SRI-W since 200X to cater for the recording and reporting accounting transactions for waqf. All waqf 
money is consolidated in a fund called the Waqf Amanah (Trust) Fund which recording of transactions is based on the accrual basis. Analysis done on SRI-W financial statement reveals the merging of financial statements between waqf khayri (waqf general) and waqf khas (waqf specific) accounts. Such nonseparation triggers critical Shari'ah issue as any income or resources of waqf khas are only applicable to specific waqf and could not be mixed with other waqf. Observably, all waqf transactions are debited or credited to this account. The expenses and income will be shown in the financial statement under the General Resources unit. Waqf transactions are traceable up to the trial balance date. Table 1 below shows the trial balance for the waqf fund:

Table 1: Waqf fund Trial Balance as at June 7, 200X (Source: SRIW's Ledger, 200X)

\begin{tabular}{|c|c|c|c|c|}
\hline No & Particular & $\begin{array}{l}\text { Classification } \\
\text { Code }\end{array}$ & $\begin{array}{l}\text { Debit } \\
(\mathrm{RM})\end{array}$ & $\begin{array}{l}\text { Credit } \\
(\mathrm{RM})\end{array}$ \\
\hline 1 & $\begin{array}{l}\text { Building } \\
\text { maintenance }\end{array}$ & 5 & 4,099 & \\
\hline 2 & $\begin{array}{l}\text { Building } \\
\text { insurance }\end{array}$ & 5 & 375 & \\
\hline 3 & $\begin{array}{l}\text { Bank } \\
\text { commission }\end{array}$ & 5 & 1.50 & \\
\hline 4 & $\begin{array}{l}\text { Accrued rental } \\
\text { Income }\end{array}$ & 1 & 13,300 & \\
\hline 5 & Rental deposit & 3 & & 5,000 \\
\hline 6 & Utilities deposit & 3 & & 988.50 \\
\hline 7 & Prepayment & 3 & & 400 \\
\hline 8 & $\begin{array}{l}\text { House rental } \\
\text { income }\end{array}$ & 6 & & 24,600 \\
\hline 9 & $\begin{array}{l}\text { Land rental } \\
\text { income }\end{array}$ & 6 & & 9,000 \\
\hline 10 & $\begin{array}{l}\text { Retained } \\
\text { earning }\end{array}$ & 7 & & 89,457 \\
\hline \multirow[t]{2}{*}{11} & \multirow[t]{2}{*}{ Cash at bank } & \multirow[t]{2}{*}{1} & 111,669 & \\
\hline & & & $129,444.50$ & $129,444.50$ \\
\hline
\end{tabular}

The classification code used reflects the nature of account i.e. assets, liabilities, equity (reserve) revenue or expenses. Waqf transactions appeared mainly on rental deposits and income as well as expenses on waqf assets such as maintenance and insurance. Interestingly, a retained earning account is also maintained for waqf funds and there is also a specific bank account for waqf transactions. Intriguingly, waqf assets were not accounted for in view that there is no assets valuation exercise been carried out and therefore, it was not capitalized.

Accounting, Reporting and Investment of Waqf Assets

In SRI-W, the GRU is entrusted to maintain waqf assets register. Analysis on such register reveals that the list does not contain assets value, which item is also unavailable in SRI-W's audited annual report for the same year. This is perplexing despite the fact that the Department of Valuation and Property Services (JPPH) (a federal government agency) provides free asset valuation to all government agencies including SRI-W. The analysis further reveals administrative errors leading to different values being reported for two waqf assets which the $\mathrm{AD}$ explained was attributed to the assets were miscounted and relevant files were misplaced.

In terms of investment, it was discovered that only properties under waqf khayri are subject to the investment exercise. Properties under waqf khas are excluded as its development and usage mode are pre-defined by the waqif (person donating the assets). All waqf properties are controlled and monitored by the Investment and Development Division (IDD) under the State Islamic Department. The IDD is headed by a CAD assisted by three ADs and an engineer. Fifteen other support staffs are also employed at clerical level. The IDD manages waqf properties which include rented houses, buildings and lands.

\section{Waqf Usufructs}

The investment returns on waqf properties are termed as waqf usufructs, which, in the case of SRI-W, would be the rental income. Analysis done on the available records reveals weaknesses in the SRI-W credit control exercise as it did not receive hundred percent of the total rental income every month as rental payments were not made promptly by some tenants. The highest rental income collected for any given month is around $80 \%$ out of the total collectible 
amount. Three tenants we identified to have more than three to six months of rental arrears amounting to approximately RM13,300. The AD explains:

"In GRU, we only have two personnel to handle various tasks including faraidh (inheritance) and fidyah (compound). This effectively constraint our effectiveness in ensuring prompt rental payment"

Table 2: Waqf Investment Rental Income (Source: SRI-W's Ledger, 200X)

\begin{tabular}{l|l|l|l|c}
\hline $\begin{array}{l}\text { Property } \\
\text { No }\end{array}$ & $\begin{array}{l}\text { Yearly } \\
\text { Rental }\end{array}$ & $\begin{array}{l}\text { Latest } \\
\text { Asset Value } \\
(\mathrm{RM})\end{array}$ & $\begin{array}{l}\text { Valuation } \\
\text { Year }\end{array}$ & $\begin{array}{l}\text { Return on Waqf } \\
\text { Asset (ROWA) }\end{array}$ \\
\hline 1 & 4,800 & 100,000 & - & $4.8 \%$ \\
\hline 2 & 4,800 & 100,000 & - & $4.8 \%$ \\
\hline 3 & 4,800 & 100,000 & - & $4.8 \%$ \\
\hline 4 & 4,200 & 77,606 & 2000 & $5.4 \%$ \\
\hline 5 & 6,000 & 133,000 & 2000 & $4.5 \%$ \\
\hline 6 & 7,200 & - & - & - \\
\hline 7 & 6,000 & 84,000 & 1993 & $7.1 \%$ \\
\hline 8 & 5,400 & 120,000 & 1993 & $4.5 \%$ \\
\hline 9 & 12,000 & 114,000 & 1992 & $10.5 \%$ \\
\hline 10 & 5,940 & 40,000 & 1992 & $14.9 \%$ \\
\hline 11 & 120,000 & $27,728,925$ & 1996 & $0.43 \%$ \\
12 & 9,600 & 240,000 & 2000 & $4 \%$
\end{tabular}

The above finding confirms the disparity in management efficiency discovered by Hoexter (1998) based on waqf practices in Algeria whereby the administrator of waqf al haramayn exercised tight follow-up of rental collection on waqf properties. A simple calculation of Return on Waqf Asset (ROWA) is performed and the results are tabulated in Table 2 above.

In terms of disbursement, investigation reveals that the usufructs were only disbursed for two purposes of building maintenance and building insurance, leaving a huge accumulated cash reserve in excess of one hundred thousand. Upon inquiry, the AD explains:

"We decided to utilize the usufructs only on expenses related to the waqf assets. The accumulated usufructs funds are however not sufficiently large enough for us to undertake big scale improvement projects on waqf assets under our management"

\section{Recommendations}

Drawing from findings presented above, relevant recommendations are outlined below. These are based on SORP 2005 currently applied by charity organizations in the UK.

\section{Waqf Accounting and Reporting}

Ideally, separate financial statements should be prepared to cater for the unique operationalization of waqf as opposed to the current practice of consolidating the financial results with those of zakat. It should contain a Statement of Waqf Activities (SOWA) and a Statement of Financial Position (SOFP) with comprehensive notes to the accounts. The SOWA should also be further divided into two types, catering for the different waqf types of khas and khayri. It could be named as The Statement of Waqf Khayri Activities (SOWKA) and The Statement of Waqf Khas Activities (SOWsA) to replace the existing profit and loss account. All respective waqf income and expenditure should be credited or debited respectively to these statements. Any excess (or deficit) should then be transferred to the SOFP as retained reserves. The reserve should be maintained at an ideal/optimum size depending on economic circumstances faced by SRI-W. This is important in view that the objective of waqf is more towards the enhancement of socio-economic conditions of the ummah by way of disbursing the usufructs rather than accumulation and retention of resources i.e. waqf assets and usufructs. Samples of SOWA and SOFP based on the available SRI-W's waqf trial balance are given below:

\section{Income}

Land rental $\quad 24,600$

Building $\quad 9,000$

33,600

Less: expenses/distribution

$\begin{array}{ll}\text { Building maintenance } & 4,099 \\ \text { Insurance on building } & 375\end{array}$

Bank charges $\quad \underline{1.50}$

$\underline{(4.476)}$

$\underline{29.124}$ 
Reporting discipline should also be enhanced by observing the reporting timeframe. The accounts should be transparently and timely reported and appropriately audited in order to ensure that SRI-W's accountability towards waqifs and other stakeholders are upheld.

\section{Current Asset}

Cash at bank

Accrued rental income

111,669

$\underline{13,300}$

124,969

Less: Current Liabilities

Rental deposit

Utilities deposit

Prepayment

Net Assets

\section{5,000}

988

400

$\underline{(6,388)}$

$\underline{118,580}$

Financed By:

Accumulated Cash Reserves $\quad 89,457$

Excess Waqf Fund for the period $\quad \underline{29,123}$

\section{Waqf Investments}

In quest of maximizing investment returns, a mixed panel or committee for waqf investments should ideally be formed which includes not only the SRI-W's council members who are Islamic scholars, but also experts in other critical areas such as finance and economics. The committee should provide effective oversight over critical investment areas especially risks management. Adequate and reasonable returns should also be targeted for waqf investment in view that the usufructs will be subsequently channeled to economic activities that will benefit the Muslim ummah, apart from ensuring the sustainability of the waqf assets by way of financing the maintenance and upkeep expenses.

\section{Conclusion}

This research explored the contemporary waqf accounting, reporting and investment practices of a selected waqf manager in Malaysia-The SRI-W. A qualitative approach to research inquiry using a single case study method was adopted and the results of documentary reviews and interviews point to observable weaknesses in the accounting, reporting and investment for waqf activities particularly on waqf assets. The available records and interviews with relevant personnel suggest large improvement void in those critical areas. However, the weaknesses are noted to provide little adverse effect on SRI-W's ability of adequately safeguarding the waqf assets. The importance of proper accounting, transparent reporting and effective management of waqf investment assets lies on the simple reasoning of the need for generating waqf growth and stability for the benefit of the Muslim ummah. This exploratory study filled the vacuum in the present waqf literature specifically on waqf financial reporting and waqf investment assets. It highlighted critical areas which other SRIs in Malaysia could reflect upon and plan appropriate strategies to overcome the weaknesses if any. Future research on waqf could look at the financing dimension which remains a stumbling block for waqf assets development. 
Suggestions in the literature on using waqf assets to back the issuance of sukuk (Islamic bond) in order to raise cash for waqf assets development could be further investigated. This is in addition to the cash waqf scheme which several SRIs have already introduced. New innovations particularly on strategic financial engineering is critically needed to provide the much needed funds in empowering the role of waqf in strengthening the Muslim ummah's economy.

\section{References}

Abdul-Hamid, M. (2003). Civil and shari'ah courts in Malaysia: Conflict of jurisdiction, Islamic law in the contemporary world, Zainal Azam Abd Rahman (Ed.). Kuala Lumpur: Institute of Islamic Understanding (IKIM).

Abdul-Rahim, A.R., Mohamad-Daud, B., and Yusuf, I. (1999). Current practices and administration of waqf in Malaysia: A preliminary study. Awqaf report (28/7/1999), Malaysia, unpublished.

Abdul-Rahim, A.R. (1998). Issues in corporate accountability and governance: An Islamic perspective. The American Journal of Islamic Social Science, 15 (1), 55-69.

Abdul-Rahim, A.R. and Goddard, A. (1998). An interpretive inquiry of accounting practices in Religious Organizations. Financial Accountability \& Management, 14 (3), 183 201.

Ahmad, I. (1999). Waqf dan perlaksanaan undang-undang di Malaysia, Konsep dan perlaksanaan waqf di Malaysia, Institut Kefahaman Islam Malaysia, 3, 29-42.

Ahmad, I. (2000). The administration of Islamic law in Malaysia. Institute of Islamic Understanding Malaysia. Kuala Lumpur: Ampang Press.

Alabij, A. J. (1989). Perwakafan Tanah di
Indonesia: Dalam teori dan praktek (Land waqf in Indonesia: Theory and practices). Jakarta, Indonesia: Rajawali Pers.

Baharuddin, S. (1998). Pentadbiran dan Pengurusan harta waqaf di Semenanjung Malaysia (Management and administration of waqf land in Peninsular Malaysia), 91-116.

Baxter, P. and Jack, S. (2008). Qualitative case study methodology: study design and implementation for novice researchers. The Qualitative Report, 13 (4), 544-559.

Bilal P. A. A. (1994). The Fundamental of tawheed: Islamic monotheism. Riyadh, Saudi Arabia: International Islamic Publishing House.

Chapra, M. U. (1992). Islam and the economics challenge, Islamic economics series. No. 17, Leicester and Nairobi: Islamic Foundation, Herndon, Va. IIIT.

Cizakca, M. (1998). Awqaf: In history and implications for modern Islamic economics. Proceedings from the 1998 International Seminar on Awqaf and economic development, Organized by IRTI, IKIM and BIRT, Kuala Lumpur, Malaysia.

Cooper, D. R and Schindler, P. S. (2003). Business Research Method. Eight Editions, McGraw-Hill.

Cordery, C., Baskerville, R. and Porter, B. (2011). Not reporting a profit: constructing a nonprofit organization. Financial Accountability \& Management, 27 (4), 363-384.

Dhanani, A. (2009). Accountability of UK charities. Public Money and Management, 29 (3), 183-190.

Deguilhem, R. (2003). On the nature of waqf: Pious foundations in contemporary Syria: A break in tradition. AWQAF, 4, 5-35.

Firestone, W.A. (1987). Meaning in method: the 
rhetoric of quantitative and qualitative research. Educational Researcher, 16 (1), 16-21.

Gillham, B. (2000). Case study research methods. Continuum, London and New York.

Hashmi, S. A. (1984). Management of waqf: past and present. Proceeding of the seminar on Management and development of Awqaf properties, Jeddah, Saudi Arabia, 4th-6th August.

Hassan, A. A. (1984). Waqf in Islamic jurisprudence. Proceeding of the seminar on Management and development of Awqaf properties, Jeddah, Saudi Arabia, 4th-16th August.

Hasanuddin, A. (1998). Strategies to develop waqf administration in India. Research paper No. 50, Islamic research and training institute (IRTI), Islamic Development Bank, Jeddah, Saudi Arabia.

Hoexter, M. (1998). Endowments, rulers and community: Waqf al Haramayn in Ottoman Algiers. Studies in Islamic law and society, 6, Brill, Netherland.

Hooper, K., Sinclair, R., Hui, D. and Mataira, K. (2008). Financial reporting by New Zealand charities: finding a way forward. Managerial Auditing Journal, 23 (1), 68-83.

Hyndman, N. (1990). Charity accountingan empirical study of the information needs of contributors to UK fund raising charities. Financial Accountability \& Management, 6 (4): 295-307.

Hyndman, N. and McDonnell, P. (2009). Governance and charities: An exploration of key themes and the development of a research agenda. Financial Accountability \& Management, 25 (1), 5-31.

Jacobs, K. (2005). The sacred and the secular: Examining the role of accounting in the religious context. Accounting, Auditing and Accountability Journal, 18 (2), 189-210.

Jacobs, K. and Walker, S.P. (2004). Accounting and accountability in the Iona community. Accounting, Auditing and Accountability Journal, 17 (3), 361-381.

Kamaruddin, N. (1992). Isu pembangunan Tanah wakaf (Waqf land development issues). Kuala Lumpur, Malaysia: Dewan Bahasa dan Pustaka.

Khan, A.A. (2002). The Indian Waqf Act 1995: Towards a better administration problems and prospects, Awqaf experiences in South Asia. Institute of Objective Studies, New Delhi, India.

Laughlin, R.C. (1988). Accounting in its social context: an analysis of the accounting systems of the Church of England. Accounting, Auditing and Accountability Journal, 1 (2), 19-42.

Lightbody, M. (1999). Storing and shielding: financial behavior in a church organization. Accounting, Auditing and Accountability Journal, 13 (2), 156-174.

Mahmood, T. (1998). Contemporary Awqaf legislation in Muslim countries and communities. International seminar on Awqaf and economic development, Kuala Lumpur, Malaysia.

Mahmood, Z.A.M. (1999). Konsep dan amalan waqf di Malaysia (Waqf in Malaysia: Concept and practices). Institut Kefahaman Islam Malaysia, 2, 17-28.

Mahmood, Z.A.M. (2000). Waqf dan perlaksanaannya di Malaysia (Waqf implementation in Malaysia). Siri Penyelidikan Yayasan Islam Terengganu, Vol. 26. Terengganu, Malaysia: Percetakan Yayasan Islam Terengganu

Maxwell, J.A. (1996). Qualitative research design: An interactive approach. Applied social research methods series 41, Sage Publications, Inc. 
Mohammad-Rizwanul, H. (2002). Waqf experience in India. Awqaf experiences in South Asia. Institute of Objective Studies, New Delhi, India.

Mohd-Daud, B. (1999). Amalan institusi waqf di beberapa negara Islam: Satu perbandingan (Waqf institutions practice in Islamic countries: A comparison). Institut Kefahaman Islam Malaysia, 7, 155-187.

Mohd-Yusop, Y. (1999). Pengurusan Tanah waqf di Perak: Amalan dan perancangan (Waqf land management in Perak). Institut Kefahaman Islam Malaysia, 5, 65-104.

Kahf, M. (1998). Financing development of Awqaf properties. International seminar on Awqaf and economic development, Kuala Lumpur, Malaysia.

Kamla, R., Gallhofer, S. and Haslam, J. (2006). Islam, Nature and Accounting: Islamic Principles and the Notion of Accounting for the Environment. Accounting Forum, 30 (3), 245-65.

Moore, N. (2000). How to do research: the complete guide to designing and managing research projects. Third Edition. London: Library Association Publishing.

Nahar, H.S. and Yaacob, H. (2011). Accountability in the sacred context: the case of management, accounting and reporting of a Malaysian cash awqaf institution. Journal of Islamic Accounting and Business Research, 2 (2), 87-113.

Nasution, K.S. (2002). Colonial intervention and transformation of Muslim Waqf Settlements in urban Penang: The role of the Endowments Board. Journal of Muslim Minority Affairs, 22 (2), 299-315.

Naqvi, N. (1981). Ethics and economics: an Islamic synthesis. Leicester, UK: The Islamic Foundation,
Nik-Mohd-Zain, Y. and Azimuddin, B. (1999). Kedudukan dan potensi pembangunan hartanah waqf di Malaysia: Satu penilaian (Waqf land development potential in Malaysia). Konsep dan perlaksanaan waqf di Malaysia, Institut Kefahaman Islam Malaysia, 6, 105-154.

O'Leary, Z. (2004). The essential guide to doing research. SAGE Publications Ltd.

Qasmi, Q.M.I. (1999). Waqf in Islamic jurisprudence. Seminar on Awqaf experiences in South Asia, IRTI, Kuwait Awqaf Public Foundation and Institute of Objective Studies, India.

Razali, O. (2004). The influences of colonization on the perception and practices of waqf. IKIM Journal, 12 (1), 41-62.

Ridzuan, A. (1994). Undang-undang tanah Islam: Pendekatan perbandingan (Islamic land laws). Lumpur, Malaysia: Dewan Bahasa dan Pustaka.

Sadeq, A.M. (2002). Waqf, perpetual charity and poverty alleviation. International Journal of Social Economics, 29 (1), 139-151.

Shatzmiller, M. (1991). Some social and economic aspects of wakf khayri in the 14th century Fez. Anaquel de Estudios Arabes, 2: 193-217.

Siti-Alawiyah S. (2004). The financial management practices of state mosques in Peninsular Malaysia. Unpublished Masters Dissertation, International Islamic University Malaysia, Malaysia.

Siti-Rokyah, M.Z. (2004). Determinants of Financial Reporting Practices on Waqf by Malaysian State Islamic Religious Council in Malaysia. Unpublished Masters Dissertation, International Islamic University Malaysia, Malaysia.

Sulaiman, E. (1987). Pentadbiran Baitulmal 
Wilayah Persekutuan sebagai contoh (Federal Territory waqf administration as example). Seminar Pembangunan Wakaf dan Baitulmal Negeri Johor, Organized by State of Johor and Institut Tadbiran Awam Negara (INTAN), Malaysia.

Sulaiman, M. (2003). The influence of riba and zakat on Islamic accounting. Indonesian Management and Accounting Review, 2 (2), 149-167.

SORP (2005). Accounting and Reporting by Charities: Statement of Recommended Practice. Charity Commission, U.K.

Syed-Khalid, R. (2002). Awqaf legislation in South Asia: A comparative study. Awqaf experiences in South Asia. Institute of Objective Studies, New Delhi, India.

Syed-Othman A. (1986). Konsep waqaf dan perlaksanaannya di Malaysia (Waqf concept and implementation in Malaysia). Seminar paper on Management and Administration of waqf property, Organized by Majlis Agama Islam Perak and Prime Minister Department, Malaysia.

Toraman, C., Tuncsiper, B. and Yilmaz, S. (2007). Cash Awqaf in the Ottomans as Philanthropic Foundations and their Accounting Practices. Fifth Accounting History International Conference, Banff, Canada, 9-11 August 2007.

Travers, M. (2001). Qualitative research through case studies. SAGE Publications.

Van-Leeuwen, R. (1999). Waqfs and urban structures: The case of Ottoman Damascus. Studies in Islamic Law and Society 11, Koninklijke Brill NV, Leiden, the Netherlands.

Yaacob, H. (2013). Waqf history and legislation in Malaysia: A contemporary perspective. Journal of Islamic and Human Advanced Research, 3 (6), 387-402.
Yaacob, H., Petra, S., Sumardi, A., and Nahar, H.S. (2015). Accountability through Accounting and Reporting Lenses. Humanomics, 31 (3): 299-313.

Yasmin, S, Haniffa, R. and Hudaib, M. (2014). Communicated Accountability by Faith-Based Charity Organizations. Journal of Business Ethics, 122 (1), 103-123.

Yedyyildiz, B. (1996). Place of the Waqf in the Turkish cultural system. English translation by R.Acun and M.Oz, proceedings of the Habitat II, Hacettepe University, Turkey, 12 April 1996.

Yin, R.K. (1994). Case study research: design and methods. 2nd Ed., Applied Social Research Methods Series 5, Sage Publications.

Zainal-Abidin, J. (1999). Pengurusan waqf di Wilayah Persekutuan: Amalan dan Perancangan (Waqf administration in the Federal Territory). Konsep dan perlaksanaan waqf di Malaysia, Institut Kefahaman Islam Malaysia, 4, 43-63.

Zain, M.O. (1971). The theory, practice and administration of waqf with special reference to the Malayan state of Kedah. Unpublished $\mathrm{PhD}$ thesis, University of St. Andrews, UK.

Zain, M.O. (1982). Islamic law with special reference to the institution of waqf. Prime Minister Department, Kuala Lumpur, Malaysia.

Zietlow, J.T. (1989). Capital and operating budgeting practices in pure non-profit organizations. Financial Accountability \& Management, 5 (4), 219-232. 